\title{
w 5-1
}

慢性関節リウマチに続発した無巨核球性血小板減少症の一例

○田中浩紀 1) 2), 酒井基 ${ }^{31}$, 沖真理子 1)21, 野島正寛 1) 2,

前森雅世 1)2), 田賀理子 1)21, 奥田博介 1), 西村進 1), 木村裕一 1), 米澤和彦 ${ }^{11}$, 阿部敬 ${ }^{11}$, 登坂松三 1 ), 今井浩三 ${ }^{2}$ )

1 市立釧路総合病院内科 2 札幌医科大学 第一内科

3 手稲渓仁会病院血液内科

症例は64 歳，女性。平成 10 年より他院にて慢性間節リウマチ（RA）の 診断にて加療を受けていた。平成 13 年 5 月 30 日，腎機能障害，血小 板减少を認めたため，当院に搬送され 1 回目の入院となった。ミゾリ ビンによる高尿酸血症及び，急性腎不全の診断にて，同薬剤の中止及 び血液透析施行にて腎機能，血小板数は改善し，7月 4 日退院となった。 以後外来にて経過観察されていたが，11月より再度，血小板数の著明 な減少を認めたため 11 月 9 日 2 回目の入院となった.入院時WBC6910， Hb 11.8, Plt 9000. 骨䯣穿刺にて, NCC $171500 / \mu 1$, Mega $0 / \mu 1$ あ あ った。血球に異形成は認めず, 無巨核球性血小板減少症 (AMT) と診断 L た.m-PSLによるパルス療法が無効で, 頻回の血小板輸血を要したため， メテロノン併用シクロスポリンによる免疫抑制療法を施行・血小板数 の増加を認め輸血非依存性となった。AMTは比較的稀な疾患で， RAに 綂発したものは検索し得た限り報告がなく興味ある症例と思われた。

w 5-2

急速に進行した原発性アミロイドーシスの 1 例

○後藤明子、向井正也、能登谷京、河野通史

(市立札幌病院 免疫血液内科)

アミロイドーシスは進行性の経過をとるといわれているが、その中においても我々は特 に急速な増悪を来した 1 症例を経験したので報告する。症例は 67 歳女性。平成 13 年 9 月に口腔乾燥症状を主訴に近医受診、シェーグレン症候群(以下 SS)を疑われ平成 14 年 1 月に当科受診した。その際に $\mathrm{M}$ 蛋白と尿蛋白陽性も認められたため精查目的に当科入院 となった。入院当初 Ss に合併する悪性リンパ腫、多発性骨䯣腫を疑ったが、骨䯠所見、 骨シンチなどから否定され、腎生検にてアミロイドを認め、原発性アミロイドーシスと診 断した。また、心エコーでもアミロイドーシスの所見が得られ、唾液腺シンチでは顎下腺 機能の高度低下がみられたが、唾液腺生検でリンパ球漫潤なく SS は否定された。さらな るアミロイドの産生抑制を目的として MP 療法、腎障害予防目的で抗凝固療法を併用した か、黄㾝の進行と腎機能の悪化がみられ、尿蛋白の減少は認めなかった。透析を導入する も反応不良で入院後 3 ケ月にて永眠された。本症例は発症後急速な進行が認められ、治 療への反応は極めて不良であった。今後アミロイドーシスを加療する上で、注意が必要と 思われたので文献的考察を加え報告する。 


\section{w 5-3}

抗ヒト型化 IL-6レセプター抗体（MRA）投与によりEBウイルス（EBV）関連 Hodgkin 病を発症した関節リウマチ（RA）の一剖検例

○小川 純、長坂憲治、富永慎一郎、鈴木文仁、小池竜司、上阪 等、

窪田哲朗、宮坂信之（東京医科歯科大学医学部 膠原病・リウマチ内科）

目的：我々は多剤抵抗性の関節リウマチ（RA）患者にMRA を投与した後、血球貪食症 候群(HPS)を併発し死亡した EBV 関連 Hodgkin 病の一例を経験した。症例：60歳女性。 30 年前に RA を発症したが、9 年前よりメトトレキサート（MTX）投与により寛解とな った。その後二度にわたり MTX 増量後に発熱、体重減少、頸部リンパ節腫脹を来たした が、MTX 中止のみで改善した。しかし、その後関節炎が増悪し、MRAの治験組入れ基準 を满たしたことから、MRA の投与を開始した。結果：MRA $8 \mathrm{mg} / \mathrm{kg}$ 投与にて関節炎は著 明に改善したが、MRA 投与開始 3 週間後より発熱、汎血球減少と肝障害、さらには黄疸、 顔面浮腫、胸水、肝脾腫が出現した。このため、HPS とそれに伴う vascular leak syndrome と考え、ステロイドパルス療法と predonisolone $60 \mathrm{mg} /$ day 、cyclosporin A $250 \mathrm{mg} / \mathrm{day}$ を開始したが、出血性胃潰瘍、肝不全、DIC を併発。また血清 EBV DNA が著増したため 慢性活動性 EB ウイルス感染症の合併も考え、自己活性化リンパ球輸注、血漿交換療法を 追加したが改善なく、8週後永眠した。剖検時に得られた腹部傍大動脈リンパ節の病理所 見より EBV 関連 Hodgkin 病と診断された。結論：抗ヒト型化IL-6レセプター抗体の投 与により EBVの再活性化が起こりうる可能性がある。

\section{w 5-4}

自家 CD34 純化末梢血幹細胞移植後に免疫機序による

血小板減少を来した強皮症の 1 例

北海道大学大学院医学研究科分子病態制御学講座 - 第二内科

○坊垣暁之（ボウガキトシユキ）、天崎吉晴、坊垣幸、片岡浩、

深江淳、古川真、酒井良江、古崎章、浄土智、市川健司、渥美達也、

西尾充史、澤田賢一、小池隆夫

[症例] 症例は 19 歳女性。1997 年にびまん性全身性強皮症と診断された。Dペニシラミン内服で皮虙硬化の改善を認めたが、ネフローゼ症候群を発症し内 服を中止した。急速な皮虙硬化の進行を認め、種々の治療に抵抗性であったた め、2000 年 10 月に治療方針決定のために当科を紹介受診した。受診時、体幹 部に及ぶ高度の皮膚硬化を認め、難治性指尖潰瘍も認めた。インフォームドコ ンセントを得た後、2001 年 3 月 21 日に自家 CD34 純化末梢血幹細胞移植を行 つた。移植後の造血能回復は速やかであり、移植後 3 ケ月の modified Rodnan total thickness skin score は $28 \rightarrow 16 / 51$ と著明な改善を認めた。外来経過観察中であ つたが、2001 年 10 月に突然血小板減少（血小板数 $8000 / \mu$ l）を来した。骨髄 穿刺、生検で異形成はなく、巨核球数も正常であった。その他、凝固異常、原 病の悪化等を認めず、PAIgG 高值も認めたことより、自己免疫機序による血小 板減少と診断した。プレドニソロン $30 \mathrm{mg} /$ 日内服で血小板数の速やかな改善を 認めた。自己兔疫疾患に対して行った純化自家 CD34 純化末梢血幹細胞移植後 に新たな自己免疫機序による疾患を発症したことから、本治療による効果は免 疫系の「リセット」というよりむしろ「修飾」であることが示唆された。 


\section{w 6-1}

自己抗体陽性であった再発性多発性軟骨炎 (RP)の一例

松本和子、鍵谷真希、川崎善子、阪本倫代、平野すずえ、

佐々木雅子、武内徹、槇野茂樹、花房俊昭

(大阪医科大学第一内科)

症例は 57 歳女性。入院時主訴は左耳介部発赤・腫脹・疼痛。平成 12 年 11 月 頃より同症状の寛解增悪認めるも放置していた。平成 13 年 6 月頃より症状が増 悪し、さらに全身倦点感も出現してきたため近医受診、精查加療目的にて当科紹 介入院となった。耳介軟骨炎、網膜剥離、鞍鼻より RPを疑い、耳介生検・3DCT ・ 気管支鏡を施行した。耳介生検ではリンパ球浸潤を伴う軟骨炎を認め、気管支鏡 にて吸気で気管軟骨の冕脱を認めるため同疾患と診断した。診断時のスクリーニ ングで抗核抗体 80 倍と弱陽性および抗 $\mathrm{ds}-\mathrm{DNA}$ 抗体陽性 $19.3 \mathrm{IU} / \mathrm{ml}$ (正常 12.0 以下）と陽性であった。本例は初回治療としてプレドニゾロン(PSL)とメトトレ キセート (MTX) 併用療法を選択したが軽快せず、さらにシクロホスファミド (CPA)を併用し寛解を得た。RPは過去の報告によると $35 \%$ に自己免疫疾患の合 併を伴い、合併症例では本疾患の発症年龃が低いとしている。一方、抗核抗体陽 性者は $66 \%$ である。本疾患は希少であることから治療法が確立しておらず、経 験的に行われているに過ぎないが、自己免疫疾患の合併も少なくない事からその 選択には注意を要すると考えて報告する。

\section{w 6-2}

コルヒチン投与が著効した家族性地中海熱の一例

$\bigcirc$ 平賀寛人、石黒 陽、山形和史、高畑武功、櫻庭裕丈 (弘前大学医学部第一内科)

【症例】36歳、男性。写真業。【主訴】周期的に繰り返す発熱と腹痛。 【既往歴】平成 6 年、虫垂炎のため虫垂切除術。【海外渡航歴】アメリカ、ヨーロッパのみ。 【家族歴】妹が周期的に繰り返す胸痛を伴う不明熱を周期的に繰り返していた。その他、 父が胆輬炎、祖母が潰瘍性大腸炎。【現病歴】12 13年前頃より周期的に発熱と腹痛が出 現。熱型は $38^{\circ} \mathrm{C}$ を超える波状熱であり、腹痛は下腹部の限局した痛みで始まり、次第に腹 部全体に及んだ。症状出現時の血液学的検查では C R P 、赤沈といった炎症マーカーの上 昇を認め、腹部単純 X線で一過性に小腸ガスの出現がみられた。症状は非ステロイド性鎮 痛薬（NSAIDs）にて軽快するも症状を繰り返すため、不明熱の診断で10年にわたり複数の 病院で精查を受けたが確定診断には至らなかった。平成 13 年 8 月 30 日、精査目的で当科紹 介入院。入院時に症状はなく、理学所見上特記すべき所見はなかった。特徴的症状と家族 歴から家族性地中海熱を疑い、発作予防目的でコルヒチン $1.5 \mathrm{mg}$ の経口投与を開始したと ころ一年以上症状は出現していない。【考察】家族性地中海熱は、民族性の問題はあるが、 一方では特徵的な症状から診断は容易とされる。我々が文献検索し得た限りでは本邦で 12 例の報告しかない。極めて稀な一例であり報告した。 


\section{w 6-3}

巨大な結腸潰崵を繰り返した全身性エリテマトーデス（SLE）の 1 例 北海道大学大学院医学研究科分子病態制御学講座・第二内科

○萩原宏美（ハギワラヒロミ）、横田美紀、古崎章、伊藤幹、橋本陶子、 近祐次郎、酒井良江、古川真、坊垣暁之、深江淳、浄士智、天崎吉晴、

市川健司、渥美達也、小池隆夫、北海道大学医学部附属病院病理部 伊藤智雄 症例は34歳女性。1991年に発熱、皮疹、関節炎などで SLEと診断された。1994年に意識障 害を発症し、NPSLと診断され、ステロイド大量療法およびシクロホスファミド大量静注 療法にて治療された。1995年 8 月下血があり、下部消化管内視鏡検查を行ったところ、直 腸に巨大潰瘍を認めた。SLEによる血管炎と考え、ステロイドパルス療法を施行したが、 同年11月に大量下血をきたしたため、直腸切除、人工肛門造設術を行った。切除標本の病 理学的検索で動静脈に閉塞性血管炎を認めた。シクロホスファミド大量静注療法は 2 年間 継続され、その後潰瘍の再発はなく経過していた。2002年 3 月末より、明らかな下血は認 めないものの、腹痛、下痢が出現した。低補体血症が進行し、抗 DNA 抗体の上昇を認めた ため同年 5 月 23 日精査目的に当科入院した。下部消化管内視鏡検査で下行結腸に多発する 巨大潰痬を認めた。腹部血管造影では明らかな閉塞性病変を認めなかったが、SLEによる 直腸潰瘍の再発と判断し、ステロイド大量療法とシクロホスファミド大量静注療法を開始 した。治療後徐々に症状は軽快し、潰瘍は縮小を認め、血清学的データも改善傾向にあ る。SLEの経過中で結腸潰瘍をきたした症例を報告する。

\section{w 6-4}

日光暴露後に発症したループス膀胱炎の一例

○本多佐保, 近藤吉宏, 赤保内良和(市立室蘭総合病院消化器科)

高橋裕樹, 今井浩三(札幌医大医学部第一内科)

症例は 20 歳男性, 数年前から関節痛と強いレイノー症状が出現し SLE 疑いで半年前から PSL10mg 内服中, H13 年 6 月下旬, 炎天下の海岸で約 1 時間過ごした直後から 39 度台の発 熱が 2-3 日続き，1 ケ月後から腹痛・下痢・嘔吐など急性胃腸炎症状を繰り返す様になった。 同じ頃から尿蛋白の増加が見られループス腎炎が疑われた，同年 10 月，腎生検前の㭘査に て右水腎症を指摘，1 1 ケ月後には左水腎症と水尿管症を指摘された. MRI にて尿管に器質 的病変や結石を認めず, CT にて腸管壁の著明な肥厚を認めたため, それまでの症状とあわ せてループス膀腅炎が強く疑われた，血液検査では抗 sm 抗体・抗 DNA 抗体陽性の他，血 清補体価の低下・免疫複合体陽性等を認めた。膀胱鏡検査では膀胱粘膜の浮腫を, 粘膜生 検にて上皮下間質のリンパ球浸潤と軽度の線維化を認め間質性膀腅炎の所見だった。また 腎生検ではループス腎炎(WHO IIb )の所見だった. 症状の発現時期等から日光暴露を引きが ねにループス腎炎とループス膀胱炎を発症した可能性が強く疑われた。12月6日当科入院 にて PSL50mg による治療を開始し 4 週後の CT にて腸管壁の肥厚は消失した。

ループス膀胱炎は膀胱に非可逆的な变化が進行してから発見される例が多く，早期には 急性胃腸炎様の非特異的症状のために見落とされ易いことが指摘されている. 今回比較的 早期に診断されたループス膀胱炎の一例を経験したので文献的考察をまじえて報告する. 
w 7-1

脳梗塞による不全片麻㾝の非麻痺側優位に皮疹と筋症状を認めた皮膚筋炎の 1 例

○濱口儒人、佐藤伸一、竹原和彦

(金沢大学大学院医学系研究科皮詹科学)

67 歳男。43 歳時に脳梗塞を発症し、以降左不全片麻痺状態であった。66 歳時進行期 胃癌に対し拡大郭清術を施行された。初診 2 ケ月前から、右半身優位の筋力低下と筋把 握痛、㾕みを伴う皮疹が出現した。初診時、ヘリオトロープ疹は両側に認められたものの、 scratch dermatitis 様の浮腫性紅斑は体幹、大腿の右側にのみ、またゴットロン徵候も右 手背にしか認められなかった。神経学的に右半身優位の近位筋の筋力低下あり、CK ( 2763 $\mathrm{IU} / \mathrm{ml}$ )、Aldolase $(15 \mathrm{IU} / \mathrm{ml})$ は著明に上昇していた。抗核抗体、抗 Jo-1 抗体は陰性。 間質性肺炎は認めなかった。右手背紅斑部の生㭘で、真皮上層の血管周囲性の炎症細胞浸 潤と液状変性を認めた。右三角筋生検では、間質の增生と細胞浸潤、筋線維の大小不同・ 壊死を認めた。腹部 CT で膵上部に腫瘤を認め、再発性の進行期胃癌に合併した皮膚筋炎 と診断した。500mg のメチルプレドニゾロン療法 1 クール施行後、水溶性プレドニソロ ン $40 \mathrm{mg}$ 投与により筋症状、皮疹、筋原性酵素は軽快したが、再発した胃癌の増悪によ り 2 ヶ月後に死亡した。非麻痖側優位に皮疹と筋症状を認めた皮膚筋炎は過去に報告は なく、極めて稀と考えられた。

w 7-2

ステロイド抵抗性亜急性間質性肺炎を合併した抗 PL-12 抗体陽性の抗アミノ アシル tRNA 合成酵素抗体症候群の 1 例

$\bigcirc$ 濱口儒人、長谷川稔、佐藤伸一、竹原和彦 (金沢大学大学院医学系研究科皮膚科学)

44 歳女。初診 4 ケ月前、レイノ一症状、両手指の腫脹、乾性咳濑、労作時呼吸困難、 $38^{\circ} \mathrm{C}$ 以上の発熱が出現。近医内科で間質性肺炎の診断のもとプレドニゾロン 1 日 $40 \mathrm{mg}$ 内服より治療を開始された。1 ケ月前から右第 II、III 指に指尖潰瘍が出現し急速に増悪 したため当科を受診した。初診時、左右 III 指に爪上皮出血点あり。胸部 X 線・CTでは 両側下肺野の間質影の増強あり。蜂巣肺形成は認めず。呼吸機能検査で拘束性障害あり。 KL-6 (3296)、SP-D (205.0ng/ml)は上昇していた。初診時、抗セントロメア抗体が陽性 であったことから、全身性強皮症と診断した。しかし、その後免疫沈降法により抗 PL-12 抗体陽性が判明し、間質性肺炎は抗 PL-12 抗体と関連していると考えられた。以上より 全身性強皮症による指尖潰瘍を伴った抗アミノアシル tRNA 合成醳素抗体症候群と診断 した。指尖潰瘍はアロプロスタジル、アルカトロバン投与により上皮化したが、労作時呼 吸困難は持続し、 $39^{\circ} \mathrm{C}$ 以上の発熱と共に胸部 CT で間質影の増悪を認めた。間質性肺炎の 増悪と考え、ステロイドパルス療法、シクロスポリン投与、月 1 回のエンドキサンパル ス療法を施行した。自覚症状は軽快したが、肺間質影、呼吸機能、KL-6 は改善していな い。自験例では、間質性肺炎の病態の把握に抗 PL-12 抗体の検出が重要であった。 
w 7-3

重症間質性肺炎を合併したamyophatic type皮虚筋炎の 1 例

○日高義彦、小林法元、山崎崇志、南雲治夫、上松一永、安井耕三 小宮山淳

（信州大学医学部小児科）

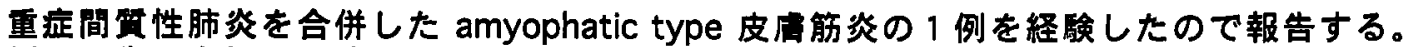

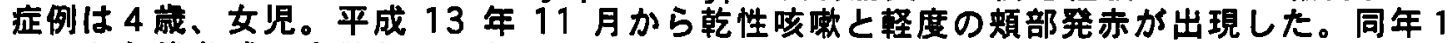
2 月から倦意感、食欲低下、体重減少か認められ、呼吸器感染症と搒断された。平成 14 年 5 月 9 日に多呼吸、低酸素血症、重症肺炎像が認められたため、当院に紹介された。入 院時血液検查では血沈の元進、LDH、GOT、GPT、IgG、KL-6、可溶性IL-2レセプター の上䙹を認めたか、CK は上昇していなかった。自己抗体は全て陰性であった。入院後、 $\mathrm{SpO}_{2}$ が低下したため人工呼吸管理を行った。筋原性醭素の上昇は珰められなかったか、、

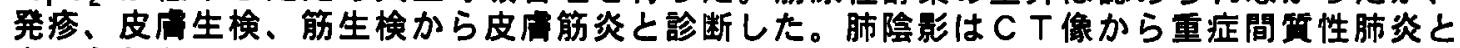
考えられた。ステロイドパルス療法、シクロスポリン投与を行ったが改善せず、5月 28 日に死亡した。

CKが上昇しない amyophatic type の皮虚筋炎では、間質性肺焱の合併を認め予後不良 となる場合がある。翏原病に合併した間复性肺炎は一般的に難治性であり早期の診断、治 療が重要である。ステロイドとシクロスポリンの併用療法が有効とされるが、本症におい ては効果は得られなかった。こうした重症例における治療法の確立が望まれる。

w 7-4

急性肝炎様の発症を呈した胆管障害を伴う自己兔疫性訮炎の一例

$\bigcirc$ 宮下真奈備 ${ }^{1}$ 、岡本良一 ${ }^{2}$ 、澤山智之 ${ }^{1}$ 、不原康裕 ${ }^{1}$ 、布山博士 ${ }^{1}$ 、三亀宏 ${ }^{1}$ 、

川口憲二 1 、湊 武 1

( ${ }^{1}$ 広島通信病院 内科 2 社会保険広島市民病院 内科)

症例は 74 歳、女性。1997 年他院で肝機能異常を指摘されたが放置。2000 年 10 月から 1 年間うこんの服用歴有り。2001 年 10 月中旬より全身倦怠感が出現し、10月24日当科 受診。T.Bil $14.9 \mathrm{mg} / \mathrm{dl}$ 、AST $1502 \mathrm{IU} / \mathrm{l} 、 A L T 1171 \mathrm{IU} / \mathrm{l} 、$ ALP $538 \mathrm{IU} / \mathrm{l} 、 \gamma-\mathrm{GTP} 240 \mathrm{IU} / \mathrm{l}$ と黄 㾝、肝機能異常が認められ入院。肝炎ウイルスマーカーは陰性で IgG $2003 \mathrm{mg} / \mathrm{dl}$ 、抗核抗 体 80 倍、抗平滑筋抗体 40 倍、1 型抗肝腎マイクロソーム抗体 $52 \mathrm{U} / \mathrm{ml}$ と自己免疫現象が 認められた 自己免度性肝炎国際診断基準(AIH)スコアは 9 点であった。UDCA、グリチ ルリチン製剤および茵陳蓓湯投与にて徐々に AST、ALT、T.Bil は低下したが 2001 年 12 月より胆道系醳素の変動がみられ、2002 年 1 月 21 日腹沿鏡検查を施行した。肝表面は自 己免疫性肝炎を疑わせる粗大起伏を認め、陥凹部に一致して赤色紋理が見られた。原発性 䏣汁性肝硬変的な所見は見られなかった。肝組織は門脈域にリンパ球主体の炎症細胞浸潤

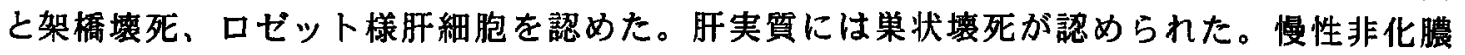
性破罗性胆管炎様の胆管障害が見られたが胆管消失や類上皮性肉芽腫は認めなかった。以 上より胆管障害を来した自己免疫性肝炎 $(\mathrm{AIH})$ と診断した。AIH でも約 $30 \%$ 症例に胆管 障害が見られるとの報告があるが、本症例では AlH にうこんによる肝障害が加わり、多 彩な組織像を呈し、興味深い症例と考えられたので若干の文献的孝察を加え報告する。 
w 8-1

間質性肺炎で発症した MPO-ANCA 関連血管炎の一例

○田幡江利子、平野すずえ、川崎善子、阪本倫代、鍵谷真希、 佐々木雅子、武内徹、植野茂樹、花房俊昭

(大阪医科大学第一内科)

症例は70歳女性。湿性咳嗽と労作時呼吸困難感を主訴に平成 9 年 7 月当科を受診。間質性肺炎と診断し、ステロイドパルス療法を行い、 その後プレドニゾロン (PSL) $50 \mathrm{mg}$ /日から内服を開始した。以後 PSL を漸減していたが平成 13 年 6 月頃より微熱を認め、以前陰性であった MPO-ANCA が陽性となり、その後もMPO-ANCA 值が上昇し関節痛が 出現、間質性肺炎像の悪化がみられた。MPO-ANCA 関連血管炎と診断 し、PSL2.5mg/日に加え経ロシクロフォスファミド(CPA) $50 \mathrm{mg} /$ 日投与 を開始した。しかし白血球減少が認められたため、CPAを減量したと ころ MPO-ANCA 值の上昇を認めたので、治療を週一回の二重濾過血墏 分離交換法とメトトレキセート $4 \mathrm{mg} /$ 週に変更した。MPO-ANCA 值は 低下傾向を示し、自覚症状も改善、画像にて間質性肺炎像も改善がみ られた。間質性肺炎を初発症状として治療経過中にMPO-ANCA 陽性と なった血管炎の一例を経験したので報告する。

w 8-2

注射金剂投与中にMPO-ANCA 陰性急速進行性系球体堅炎(RPGN)を合併した 関節リウマチ（RA）の一例

O副岛 誠，設案 久美，志関 真理子，太田 佔二，西成田 其

（日立彆作所多贺給合病院リウマチ膠原病センター）

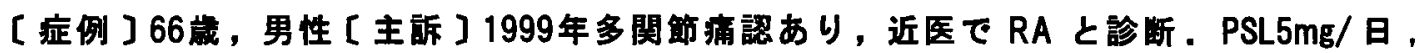
注射金剂 $25 \mathrm{mg} /$ 㥜およぴactarit $300 \mathrm{mg} /$ 日の投与を開始された．2001年 9 月より下肢の浮䇄 が出現した．同年12月には呼吸困難あり，胸水貯溜を認め肺炎の診断で抗生剂投与を受け るも改善せず，またPSL10mg/日の投与にてもRAの control不良のため，2002年 1 月当七 ンター受診，入院となった：【入院時所見】眼球結膜；貟血(-)黄染(-), 胸部; 両下肺野に

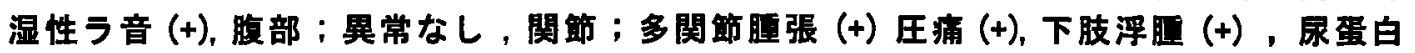
6.4g/ 日, CCr $89.1 \mathrm{ml} / \mathrm{min}, W B C 12440 / \mu \mathrm{l}, \mathrm{Hb} 12.6 \mathrm{~g} / \mathrm{dl}, \mathrm{P} 5.1 \mathrm{~g} / \mathrm{dl}, \mathrm{sCr} 0.8 \mathrm{mg} / \mathrm{dl}, \mathrm{CRP} 1.16 \mathrm{mg} / \mathrm{dl}$, $\operatorname{ANA}(-)$, aDNA $(-), \operatorname{MPO}-\mathrm{ANCA}(-)$ ，胸部 X 線 CT 再側性の胸水睁留あり.

〔経過〕蛋白尿強陆性で低蛋白血症を認めネフローゼ症候群と診断した：肾障䒠の原因と してアミロイドーシス・薬剂性腎障害が考えられ，叒生検を施行．系球体に半月体形成を 認め，臨床像とあわせて RPGN と診断．ステロイド大目投与・エンドキサンパルス都法に

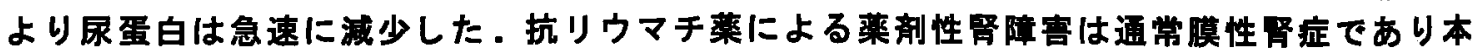
例のようにRPGN を呈することは梗めて稀と聿えられるが，過去にはペニシラミンによる RPGN も報告されており，金製都が病態の形成に関与した可能性は否定できない，RAに おける堅病変を考える上で示唆に富む症例と考え報告する。 


\section{w 8-3}

剖検でW e g e n e r 肉芽腫症を認めなかった P R 3-A N C A 高值陽性 S L E の 1 例 ○川井恵子, 葉久貴司, 日浅光春

（徳島市民病院内科）

P R 3-A N C A は W e e n e r 肉芽腫症に特異的な抗体と考元られており，他の疾 患で陽性となることはあっても高值を示すことは極めて稀である。我々は，PR 3-A N C A が高値陽性であったが, 剖検でW e g e n e r 肉芽腫症を認めなかった S L E の 1 例 を経験したので報告する。症例は71歳男性。慢性関節りウマチと診断され治療中であった。 平成 12 年 7 月，貧血と血尿，便潜血反応陽性を指摘された。平成 12 年 12 月, $38^{\circ} \mathrm{C}$ の発熱が 続き慢性関節リウマチの急性増悪との診断を受け, 副腎皮質ステロイドホルモンの投与を 受けたが解熱せず，血尿亡下痢が続き貧血が進行するため，平成 13 年 2 月 5 日当院に入院し た。意識は頃眠, 抗核抗体640倍, 抗ds D N A 抗体陽性, 溶血性䝷血と血小板減少などか らS L E と診断した。副腎皮質ステロイドホルモン, シクロホスファミドを投与したが貧 血や血小板減少は改善せず, 溶血はさらに進行し, $\mathrm{Hb} 6.0 \mathrm{~g} / \mathrm{d} 1, \mathrm{~T}-\mathrm{bi} 124.5 \mathrm{mg} / \mathrm{d} 1$ 之著明な 筫血と黄疸を呈した。またフィブリノーゲン低下，FDP上昇をきたし，血小板は500/ $\mu 1$ に減少し，出血傾向著明となった。入院前より続いていた下㾥に加え，血便も見られるよ うになり，さらに腹膜炎を合併し死亡した。PR 3 - A N C A が500 U / m I 以上と高值で あったためW e g e n e r 肉芽腫症の合併を考元剖検を行ったが肉芽腫は㒛めなかった。 本例により P R 3 - A N C A 産生機序の多様性が示唆されると考えられた。

\section{w 8-4}

顆粒球除去療法が有効であった潰瘍性大腸炎の 1 男児例

○中野景司、辻 章志、河崎裕英、小林陽之助

(関西医科大学小児科)

〔緒言〕ステロイド抵抗性謴瘍性大腸炎の7歳男児に顆粒球除去療法を行った。臨床経過 に加え、除去療法前後での好中球機能を検討したのでその結果も報告する。

〔症例と方法〕7歳の男児。潰陽性大腸炎と診断され、サラソスルファピリジン、 メサラジン、プレドニゾロン、メチルプレドニゾロン・パルス療法を行ったが無効であった ため、顆粒球除去療法（アダカラム）を行った。顆粒球除去療法は 1 週間に 1 回を 5 週連続 で行った。橈骨動脈に $22 \mathrm{G}$ を留置し、30 ml/分で脱血、中心静脈カテーテルに返血し、1 回 あたり $1,800 \mathrm{ml}$ の血液を処理した。除去療法前後に採血し、DAF2/DAを用いて好中球細胞 内一酸化窒素（NO）産生量を測定した。

〔結果〕顆粒球除去療法中は血管の閉塞や血圧の変動、その他の副反応はみられず予定量を 処理できた。1 回目の除去療法後から、便性の改善と便回数の減少とを認め、3 回目終了後 に寛解を得た。好中球の平均NO産生量は、除去療法後は前に比べ著しい減少を認めた。

〔考察】7歳の男児に顆粒球除去療法を安全に行うことができ、臨床症状の改善をみた。好 中球 NO 産生量が著しく低下したことから、顆粒球除去療法はNO 産生量の多い活性化され た好中球をより選択的に除去することが示された。 